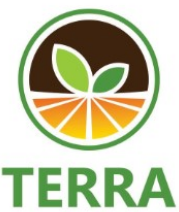

Journal of Land Restoration

\title{
Growth Response and Yield Of Sweet Corn on Palm Oil Sludge and Dolomite In Ultisols
}

\author{
Herry Gusmara $^{1}$, Ricci Handoko Silitonga ${ }^{2}$, Bilman Wilman Simanihuruk ${ }^{2}$ \\ ${ }^{1}$ Soil Science Department, University of Bengkulu (Corresponding author) \\ ${ }^{2}$ Agronomy Department, University of Bengkulu \\ e-mail:gusmara14@yahoo.com
}

\begin{abstract}
Sweet corn is a very popular agricultural commodity in Indonesia, so the production of sweet corn needs to be increased. One of the problems that often encountered in the field is the lack of availability of fertile land that can support the growth of sweet corn. Therefore it needs technology to increase land productivity. In this case, the use of palm oil sludge as a source of organic matter and dolomite as a material that can improve soil fertility. The purpose of this research is to get the dosage of palm oil sludge and dolomite that optimal for the growth and yield of sweet corn. This research was conducted from December 2017 to March 2018 in Air Sebakul Village, Talang Empat Subdistrict, Central Bengkulu using Randomized Completely Block Design with two treatment factors. The first factor is the dosage of palm oil sludge consisting of three levels, namely 0 tons $\mathrm{ha}^{-1}, 10$ tons ha ${ }^{-1}$, and 20 tons $\mathrm{ha}^{-1}$. The second factor is dolomite dosage consisting of four levels, namely 0 tons $\mathrm{ha}^{-1}, 2$ tons $\mathrm{ha}^{-1}, 4$ ton $\mathrm{ha}^{-1}$, and 6 ton ha ${ }^{1}$ so that 36 sample units are obtained. The results showed that the best combination was obtained from 10 ton ha ${ }^{-1}$ palm oil sludge and 3,61 tons ha ${ }^{-1}$ dolomite, which was able to produce the diameter of corn crop stalks of 1,98 cm. The single palm oil sludge treatment gave no significant effect on all growth and yield variables. The addition of dolomite dosage up to 6 tons $\mathrm{ha}^{-1}$ was able to increase plant height, total leaf area, the weight of corn without cornhusk, length of corn without cornhusk, a diameter of corn without cornhusk, fresh weight of the plant, and dry weight of the plant.
\end{abstract}

Keywords: palm oil sludge; dolomite; sweet corn

\section{INTRODUCTION}

Sweet corn is an agricultural commodity that is very popular with people in Indonesia. It has a sweet taste and contains lots of carbohydrates, but has a low-fat content. Sweet corn cultivation has the opportunity to provide relatively high profits. The consumption of sweet corn continues to increase and almost all parts of sweet corn have economic value, such as stalks and leaves as animal feed, compost fertilizer, and green fertilizer (Purwono \& Hartono, 2007). This encourages farmers to make improvements to the cultivation system to increase sweet corn production.

One effort that can be done in increasing sweet corn production is by increasing land productivity. Bengkulu Province is generally dominated by Ultisols covering 706,000 ha (Hidayat \& Mulyani, 2003). Ultisols have properties that can inhibit plant growth. Some common problems of Ultisols are high soil acidity (average $\mathrm{pH}<4.5$ ), high exchangeable $\mathrm{Al}$, low water retention, low nutrient content, and low organic matter content. Soil reaction (low soil $\mathrm{pH}$ ) causes less availability of nutrients in the soil. It causes the plants experience nutrient deficiency which results in suboptimal crop yields (Ispandi \& Munip, 2005). The complexity of the problems in Ultisols requires several alternatives to increase soil productivity. One way that can be done is to use technology that can improve soil properties. Some materials that can be used to improve soil conditions are the application of organic matter and dolomite.

Organic matter plays a role in improving physical, chemical, and biological soil properties. Giving organic matter can increase soil nutrients, improve soil structure, maintain aggregate stability, increase soil moisture content, and source of energy for soil organisms. Palm oil sludge is a potential source of soil organic matter in Bengkulu Province. In addition to the abundant waste production due to the activities of palm oil mills, the elemental content also has the potential as an organic fertilizer. Palm oil 
sludge nutrient content is dominated by $\mathrm{N}(27.03 \mathrm{~kg}$ ton $^{-1}$ of dry weight), $\mathrm{P}_{2} \mathrm{O}_{5}$ (2.54 kg ton ${ }^{-1}$ of dry weight), $\mathrm{K}_{2} \mathrm{O}$ (15.5 kg ton ${ }^{-1}$ of dry weight), $\mathrm{CaO}\left(14.20 \mathrm{~kg} \mathrm{ton}^{-1}\right.$ of dry weight), and $\mathrm{MgO}\left(7.36 \mathrm{~kg} \mathrm{ton}^{-1}\right.$ of dry weight). The $\mathrm{C} / \mathrm{N}$ ratio is relatively low at 5 (Wahyono et al., 2008). The application of $150 \mathrm{~kg} \mathrm{ha}^{-1}$ of NPK pearl +20 tons ha ${ }^{-1}$ of palm oil sludge gives the best growth and yield on variable plant height, dry weight of upper biomass, the weight of 100 seeds, and dry weight of corn plants (Nugroho et al., 2017). In addition to oil palm oil sludge, another material that can be used to increase Ultisols productivity is dolomite.

Dolomite is a form of agricultural lime that has a $\mathrm{MgO}$ content of $20 \%$ and $\mathrm{CaO}$ of $33 \%$ which can increase soil $\mathrm{pH}$ and can suppress exchangeable Al (Nyakpa et al., 1988). Dolomite can improve soil chemical properties by decreasing the content of exchangeable $\mathrm{Al}$, increasing $\mathrm{Ca}$ and $\mathrm{Mg}$ content, and the availability of $\mathrm{P}$ in the acid dry land. Jumakir et al. (2000) showed that liming 1 ton ha ${ }^{-1}, 50 \mathrm{~kg}$ urea ha ${ }^{-1}, 180 \mathrm{~kg} \mathrm{SP}^{2} \mathrm{ha}^{-1}$, and $50 \mathrm{~kg} \mathrm{KCl} \mathrm{ha-1}$ gave the highest production of peanut dry pods, which was 2.28 tons $\mathrm{ha}^{-1}$. While Ermadani's research (2010) showed that liming and fertilizing can increase N, P, and K uptake and the dry weight of calopogonium plants in liming 4 tons dolomite ha- ${ }^{-1}, 50 \mathrm{~kg}$ urea ha ${ }^{-1}, 250 \mathrm{~kg}$ SP-36 ha ${ }^{-1}$, and $50 \mathrm{~kg} \mathrm{KCl} \mathrm{ha}^{-1}$.

Considering that palm oil sludge and dolomite have high potential on dry land that can improve the biological, physical, and chemical properties of acidic soils, it is necessary to study the effect of palm oil sludge as a source of organic material and liming which is believed to increase yields of sweet corn on Ultisols.

This study aims to: (1) determine the interaction between oil palm oil sludge and dolomite on the growth and yield of sweet corn, (2) determine the optimal dose of palm oil sludge for growth and yield of sweet corn, and (3) determine the optimal dolomite dose for sweet corn growth and yield.

\section{MATERIAL AND METHOD}

This research was conducted in December 2017 to March 2018 in the Air Sebakul Village, Talang Empat District, Bengkulu Tengah on the map coordinates $3^{\circ} 50 ' 27.1^{\prime \prime S} 102^{\circ} 21^{\prime} 44.4^{\prime \prime} \mathrm{E}$ with a height of $\pm 17 \mathrm{~m}$ above sea level.

Materials and tools used in this study consisted of Bonanza F1 sweet corn seeds, carbofuran, NPK Mutiara 16-16-16 fertilizer, and dolomite. Palm oil sludge was taken from PT Agri Andalas Seluma. Three-ring calipers $(150 \times 0.05 \mathrm{~mm})$, cutters, digital scales, raffia cords, hand sprayers, tarpaulins, labels, ovens, cameras, and stationery.

The design used in this experiment was a Randomized Completely Block Design (RCBD) with two treatment factors. The first factor is the dose of palm oil sludge (L) which consists of 3 levels of treatment namely L0: 0 tons ha ${ }^{-1}$; L1: 10 tons $\mathrm{ha}^{-1}$, and L2: 20 tons $\mathrm{ha}^{-1}$. The second factor is the dose of dolomite (D) which consists of 4 levels, namely $\mathrm{D}_{0}$ : 0 tons ha ${ }^{-1} ; \mathrm{D}_{1}: 2$ tons ha ${ }^{-1} ; \mathrm{D}_{2}: 4$ tons ha ${ }^{-1}$, and $\mathrm{D}_{3}: 6$ tons ha ${ }^{-1}$. From these two factors, 12 treatment combinations were obtained, each treatment was repeated 3 times, so 36 experimental units were obtained.

The initial stage of this research begins with analyzing the soil before planting in a composite. Determination of the place of soil sampling conducted by purposive sampling of 5 different points, so that it can represent the condition of the entire planting area. The soil surface is cleaned of litter, grass, or other ground cover plants. Then take soil samples in the topsoil with a depth of $0-20 \mathrm{~cm}$ by $0.5 \mathrm{~kg}$, taking into account that most nutrients are at this depth. Soil that has been taken from each point, then compiled by mixing into a bucket and stirring evenly (Ahmad, 2010). Soil that has been stirred and then taken as much as $0.5 \mathrm{~kg}$ and taken to the soil science laboratory to be analyzed of $\mathrm{N}, \mathrm{P}, \mathrm{K}, \mathrm{pH}$, exchangeable $\mathrm{Al}, \mathrm{CEC}$, and $\mathrm{C}$-organic levels.

Land preparation is done by clearing the land of weeds and crop residues using sickles. Land cultivation is done twice. The first land cultivation is done two weeks before planting. The soil is cultivated using a hoe by turning the soil over and breaking up lumps of soil until the soil becomes loose. The second land cultivation is done one week before planting by loosening the soil using a hoe. Land that has been cleaned and cultivated is then made as many as 36 plots with a size of $2.8 \mathrm{~m} \times 3.2 \mathrm{~m}$, with spacing between plot $0.5 \mathrm{~m}$ and spacing between block is $1 \mathrm{~m}$. The surface of cultivated soil at each plot is leveled to be ready for planting.

Application of palm oil sludge and dolomite is done one week before planting by sprinkling on the surface of the soil according to the treatment dosage of each experimental unit, then mixing evenly using a hoe. That mixing is expected to be evenly distributed with the tillage layer.

Planting is done by digging a planting hole at $5 \mathrm{~cm}$ from the ground surface. Then each planting hole is given carbofuran 3-5 grains per planting hole. Two seeds are planted in each planting hole, then covered with soil. The planting distance used was $70 \mathrm{~cm}$ x 40 $\mathrm{cm}$ (Syukur \& Aziz, 2013), so that 32 plot $^{-1}$ plants were obtained. Then do the determination of plant samples in a structured manner. The sample plants were determined as $20 \%$ of the total population of each experimental unit. Thus, there were 216 plant samples. Sample plants were used for observing the vegetative and generative phases of sweet corn plants.

Basic fertilizer is given when sweet corn has 3 to 4 plumules. The basic fertilizer used is NPK fertilizer 
with the recommended basic fertilizer for sweet corn plants is NPK $150 \mathrm{~kg} \mathrm{ha}^{-1}$ (Sari et al., 2017). Fertilizer was applied as side placement at a row of plants and then covered with soil.

Observation variables measured in sweet corn plant samples were: plant height $(\mathrm{cm})$, stalk diameter $(\mathrm{cm})$, number of leaves (blade), level of the greenness of leaves measured during the final vegetative phase, total leaf area $\left(\mathrm{cm}^{2}\right)$ was measured 1 time ie in the final vegetative period using a cloth meter. The leaves observed were on the fourth leaf using the leaf area method (LA= length $\mathrm{x}$ width $\mathrm{x} 0.731$ ) and multiplied by the number of leaves in one sample plant (Susilo, 2015) then averaged to obtain data that represented the population in each plot, the weight of corn without any cornhusk, length of corn without any cornhusk $(\mathrm{cm})$, the diameter of corn without any cornhusk $(\mathrm{cm})$, plant fresh weight $(\mathrm{g})$, and plant dry weight $(\mathrm{g})$.

Data were analyzed statistically with Analysis of Variance (ANOVA) at a 5\% level. F test results that show the real effect of the Polynomial Orthogonal method to obtain response patterns (Gomez \& Gomez, 1984).

\section{RESULT AND DISCUSSION}

This research was conducted in December 2017 to March 2018 in the Air Sebakul Village, Talang Empat District, Bengkulu Tengah on the map coordinates $3^{\circ} 50^{\prime} 27.1^{\prime \prime} \mathrm{S} 102^{\circ} 21^{\prime} 44.4^{\prime \prime} \mathrm{E}$ with a height of $\pm 17 \mathrm{~m}$ above sea level. The land is located in the middle of a rubber plantation far from residential areas with relatively flat and open land conditions, so the plants can receive optimal sunlight. The land used during this study included fallow land with Ultisols type. Initial soil analysis results show that soil $\mathrm{pH}$ is 4.5 , which is classified as acidic, total $\mathrm{N}$ soil is $0.24 \%$, which is classified as moderate, soil C-Organic content is $2.91 \%$, which is classified as moderate, $\mathrm{P}$-available soil is $4.19 \mathrm{ppm}$ which is classified as low, K-available land is 7,40 me $100 \mathrm{~g} \mathrm{~g}^{-1}$ is classified as moderate, exchangeable Al soil is 1,25 me $100 \mathrm{~g}^{-1}$ which is classified as high, and CEC is $25,038 \mathrm{me} 100 \mathrm{~g}^{-1}$ which is classified as moderate.

Sweet corn plants have a high growth rate with growing power reaching $90 \%$. Climatology data during the study, rainfall ranged from $197.1 \mathrm{~mm} /$ month to $370.6 \mathrm{~mm} /$ month with total rainfall of $970.4 \mathrm{~mm}$. The total water requirement of corn plants ranges from $700-800 \mathrm{~mm}$, namely $300 \mathrm{~mm}$ during the vegetative phase and $400-500 \mathrm{~mm}$ in the generative phase (Muamar et al., 2012). Based on rainfall data, it can be stated that the availability of water during the growth period of sweet corn plants is sufficient so that irrigation is only done a few times when the soil is dry or when it does not rain and the rest is not watered.

Growth and yield of sweet corn plants in this study have not reached the maximum when compared with the description. However, sweet corn plants can grow normally. When sweet corn plants are 70 days old, the pests that attack are grasshoppers with a low attack rate and have no significant effect. Weeds that grow in the study area have rapid growth, so weeding and piling are carried out three times, namely at 21 , 35 , and 49 days after planting.

Sweet corn plants start flowering at 62 days after planting (DAP) and harvest is carried out simultaneously at the age of 83 DAP which is characterized by the hair of corn undergoing a brown color change, the com is full, or by pressing the sweet corn seeds that have secreted liquid such as pasta (Syukur \& Aziz, 2013).

Analytical data on growth and yield components of sweet corn are shown at Table 1 . The results of this research showed that the interaction between palm oil sludge and dolomite showed no significant interaction for all growth and yields components, except for the stalk diameter of the plant. The effect of palm oil sludge as a single factor has no significant effect on all growth and yields components, while the effect of dolomite as a single factor gives a real effect on all variables observed except on the number of leaves and the level of the greenness of the leaves.

Table 1. Resume of calculated F-5\% of the effect of palm oil sludge and dolomite on growth and yield of sweet corn

\begin{tabular}{|c|c|c|c|c|}
\hline \multirow[b]{2}{*}{ No } & \multirow[b]{2}{*}{ Variables } & \multicolumn{3}{|c|}{ Calculated F 5\% } \\
\hline & & $\begin{array}{l}\text { Palm Oil } \\
\text { Sludge } \\
\text { (L) }\end{array}$ & $\begin{array}{l}\text { Dolomite } \\
\text { (D) }\end{array}$ & Interaksi \\
\hline 1 & Plant height & $0,86 \mathrm{~ns}$ & $4,70 *$ & $1,64 \mathrm{~ns}$ \\
\hline 2 & Stalk diameter & $1,76 \mathrm{~ns}$ & $8,01 *$ & $2,80 *$ \\
\hline 3 & Number of leaves & $2,65 \mathrm{~ns}$ & $3,00 \mathrm{~ns}$ & $1,30 \mathrm{~ns}$ \\
\hline 4 & Greenish leaves & $0,29 \mathrm{~ns}$ & $1,00 \mathrm{~ns}$ & $0,81 \mathrm{~ns}$ \\
\hline 5 & Total leaf area & $1,62 \mathrm{~ns}$ & $5,88 *$ & $2,13 \mathrm{~ns}$ \\
\hline 6 & $\begin{array}{l}\text { Weight of corn } \\
\text { without any cornhusk }\end{array}$ & $0,54 \mathrm{~ns}$ & $3,90 *$ & $1,18 \mathrm{~ns}$ \\
\hline 7 & $\begin{array}{l}\text { Lenght of corn } \\
\text { without any cornhusk }\end{array}$ & $0,61 \mathrm{~ns}$ & $4,40 *$ & $0,96 \mathrm{~ns}$ \\
\hline 8 & $\begin{array}{l}\text { The diameter of corn } \\
\text { without any cornhusk }\end{array}$ & $0,74 \mathrm{~ns}$ & $4,15 *$ & $1,31 \mathrm{~ns}$ \\
\hline 9 & $\begin{array}{l}\text { Fresh weight of corn } \\
\text { plant }\end{array}$ & $1,23 \mathrm{~ns}$ & $4,93 *$ & $2,39 \mathrm{~ns}$ \\
\hline 10 & $\begin{array}{l}\text { The dry weight of } \\
\text { corn plant }\end{array}$ & $1,29 \mathrm{~ns}$ & $3,75^{*}$ & $1,06 \mathrm{~ns}$ \\
\hline 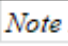 & $a s=n o n-s$ & $e n t *=$ & aifican & fferen \\
\hline at $F 5^{\circ}$ & & & & \\
\hline
\end{tabular}


The response of the stalk diameter of the sweet corn plant to dolomite application at 0 tons of palm oil sludge $\mathrm{ha}^{-1}$ formed a positive linear curve with a regression equation $\mathrm{y}_{0}=1.5521+0.0416 \mathrm{x}$. The value of $\mathrm{R}^{2}$ shows that the contribution of dolomite dose to the variation of the stalk diameter variable is $15.29 \%$. Figure 1 shows that the addition of dolomite doses up to 6 tons $\mathrm{ha}^{-1}$ to the palm oil sludge dose of 0 tons $\mathrm{ha}^{-1}$ is accompanied by an increase in the stalk diameter of sweet corn plants, but the optimum dolomite dose has not been obtained. The largest mean stalk diameter is $1.85 \mathrm{~cm}$ at a dolomite dose of 6 tons $\mathrm{ha}^{-1}$.

The dolomite dosage of 10 tons $\mathrm{ha}^{-1}$ palm oil sludge forms a quadratic curve with the equation $\mathrm{y}_{1}$ $=1.5294+0.2606 \mathrm{x}-0.0361 \mathrm{x}^{2}$ and has an $\mathrm{R}^{2}$ determination coefficient of 0.7936 (Figure 1 ). The $\mathrm{R}^{2}$ value shows that the contribution of dolomite dose to 10 tons $\mathrm{ha}^{-1}$ palm oil sludge to the variation of the stalk diameter variable of the sweet corn plant is $79.36 \%$. Giving dolomite in palm oil sludge 10 tons ha ${ }^{-1}$ initially can increase the stalk diameter of plants to reach a maximum stalk diameter of $1.98 \mathrm{~cm}$ at an optimum dolomite dose of 3.61 tons $\mathrm{ha}^{-1}$, then giving the dose above the optimum will cause a decrease in plant stalk diameter of sweet corn to the highest dolomite dose tested.

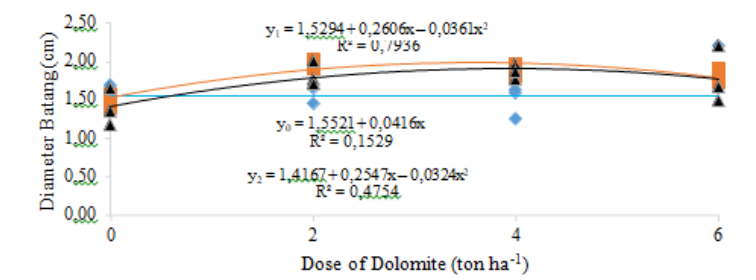

Figure 1| The relationship of dolomite dose to the stalk diameter of sweet com plants at 3 levels of palm oil sludge

Palm oil sludge: 0 ton ha-1 $\left(y_{0}\right), 10$ ton ha-1 $\left(y_{1}\right), 20$ ton ha-1 $\left(y_{2}\right)$.

Giving dolomite dose in palm oil sludge 20 tons $\mathrm{ha}^{-1}$ to the stalk diameter of the plant to form a quadratic curve with the equation $\mathrm{y}_{2}=1.4167+$ $0.2547 \mathrm{x}-0.0324 \mathrm{x}^{2}$ and the coefficient of determination $\mathrm{R}^{2}$ of 0.4754 (Figure 1). $\mathrm{R}^{2}$ value indicates that the contribution of dolomite dose to palm oil sludge 20 tons $\mathrm{ha}^{-1}$ to the variable variation in plant stalk diameter is $47.54 \%$. In the 20 tons ha ${ }^{-1}$ palm oil sludge addition of dolomite dosage at an optimum concentration of 3.93 tons, $\mathrm{ha}^{-1}$ can produce a maximum stalk diameter of $1.88 \mathrm{~cm}$, further increasing the dolomite dosage above the optimum will cause a decrease in plant stalk diameter to the highest dolomite concentration tested.

Based on the above results, the best treatment combination is a combination of 10 tons $\mathrm{ha}^{-1}$ palm sludge and 3.61 tons ha ${ }^{-1}$ dolomite dose which results in an average stalk diameter of $1.98 \mathrm{~cm}$. The increase in plant stalk diameter is thought to be influenced by soil conditions that can provide the availability of $\mathrm{K}$ nutrients obtained from the addition of palm oil sludge and dolomite. The availability of nutrients $\mathrm{K}$ can help the process of translocation of starch into the stalk circumference of the plant more smoothly to form a maximum stalk circumference. The utilization of high $\mathrm{K}$ nutrients for plants causes the plant growth process in the vegetative period to be more dominant in compiling and stabilizing cell walls. Potassium is needed by plants for cell formation in plant tissues such as stalks to strengthen the stalks so they do not easily fall on natural ecosystems (Thompson \& Troeh, 1978).

Plants that are sufficiently K can maintain the water content in the tissue which causes the development of stalk diameter to be maximal because it can absorb moisture from the soil and bind water so that the plant is resistant to drought stress. The content of available $\mathrm{K}$ in the initial soil analysis of 7.40 me $100 \mathrm{~g}^{-1}$ is classified as moderate, it is thought to have been able to meet the needs of $\mathrm{K}$ in sweet corn plants in the formation of a maximum stalk diameter. Leiwakabessy (1998) states that K plays a role in increasing the diameter of plant stalks, especially in its role as a network that connects the roots and leaves of plants in photosynthesis. Increasing the rate of photosynthesis will produce photosynthates which can increase the diameter of the stalk of the plant. The soil conditions in this study are thought to be able to provide nutrients needed by plants through liming which has been carried out according to the optimum dose of 3.61 tons ha ${ }^{-1}$. Therefore the addition of palm oil sludge and dolomite in the above doses can provide the optimum plant stalk diameter.

Palm oil sludge has the potential to increase soil fertility because it has organic material and nutrient content (Jenny \& Suwadji, 1999). The provision of oil palm oil sludge in this study had no significant effect on all observed variables. Sweet corn plants give the same response to all doses of palm oil sludge given, this shows that the elements needed by plants have been fulfilled through the nutrient content in the soil.

The results of the initial soil analysis in this study, the level of C-organic in the land used is included in the medium category, which is $2.91 \%$. Corganic content has a role in improving soil structure and porosity, increasing nutrient availability in the soil, energy sources for microorganisms, and can increase soil fertility (Adiningsih et al., 1995). This is thought to be one of the factors causing the absence of significant differences in the treatment of the dose of palm oil sludge given to growth and yield variables due to the fulfillment of nutrients needed from the soil. This can occur because the Corganic content in the soil is already high so the provision of palm sludge does not provide a real response 
to the growth and yield of sweet corn. Based on Liebig's minimum law (Salisbury \& Ross, 1992), nutrients below the optimum will inhibit growth along with the addition of the optimal dose of fertilizer, after that, it will be remain (level off) or decrease even though the dose is increased. Whereas plant growth is limited by the presence of the most limited nutrients, regardless of the number of other nutrients available.

The results of Pandapotan's research (2016) showed that the application of palm oil sludge did not significantly affect the improvement of N-total, exchangeable $\mathrm{K}$, and CEC. This is by the study of Marvelia \& Sri (2006) which shows the application of organic material from vermicompost (C/N 35.25 with a dose of $125 \mathrm{~g}$ of plant $^{-1}, 250 \mathrm{~g}$ of plant ${ }^{-1}$, and $375 \mathrm{~g}$ of plant $^{-1}$ giving production which is lower than without using vermicompost. This is following research by Fachdarisman (2013) which shows that the provision of organic material of sugarcane $(\mathrm{C} / \mathrm{N}$ 26.62) at a dose of 0 tons ha ${ }^{-1}, 5$ tons ha ${ }^{-1}, 10$ tons $\mathrm{ha}^{-1}$, and 20 tons ha ${ }^{-1}$ no significant effect on plant height, total leaf area, leaf area index, flowering age, ear length, ear diameter, number of kernel seeds ear $^{-1}$, fresh ear weight plant ${ }^{-1}$, ear weighted plot $^{-1}$, ear weight without husk $\operatorname{plot}^{-1}$, and ear weight ha ${ }^{-1}$. The results of Gustianty \& Hasibuan's research (2017) show that independent application of palm oil sludge does not significantly affect the vegetative variables of mustard plants, namely height and number of leaves aged 1 and 2 weeks after planting.

The high amount of organic matter in the soil in this study can also improve the ability of the soil to bind water. According to Soepardi (2000), organic matter can improve soil structure due to increased soil porosity, so that the ability of the soil to bind water is increasing. Sweet corn plants require large amounts of water in their growth and development. However, excessive water conditions in the soil will interfere with nutrient uptake by plant roots due to lack of oxygen. Based on rainfall data shows that the sweet corn planting period is done in the rainy season with a total rainfall of $970.4 \mathrm{~mm}$ so that water saturation occurs in the soil which causes a decrease in soil oxygen content. Bradford \& Yang (1981) states that due to limited $\mathrm{O}_{2}$ around the roots of corn plants causes unstable transport of nutrients and water to the leaf tissue. The process can reduce the leaf water potential which results in the closing of the stomata, thereby reducing the photosynthate produced. Water saturation in the soil is suspected to be one of the factors causing the treatment of palm oil sludge that has no real effect. McFarlane \& Wiliamson (2001) states that water saturation causes soil pores to become oxygen depressed, while plants need oxygen for respiration and growth. This water saturation can reduce yields between $30-80 \%$ in some crops.
The utilization of organic material can increase soil fertility because it can improve soil structure, increase water holding capacity, soil microorganism activity, nutrient availability, and nutrient reserve (Sutedjo, 2010). This organic material has a residual effect where the nutrients contained therein gradually become free and available to plants, even the residual effect is still effective 3 to 4 years after application (Hakim \& Sediyarsa, 1986). Sutriadi et al. (2005) showed that the application of organic matter by 2 tons ha ${ }^{-1}$ could increase corn production by as much as $6 \%$ in the first season, while in the second season it was able to increase corn production by $40 \%$ in the control treatment as well as with organic matter. This shows that the application of organic material is generally only seen in the second growing season. This happens because the availability of nutrients from organic fertilizer is slower and requires a longer decomposition time. Siagian et al. (2018) showed that the time of application of 15 tons of palm oil sludge $\mathrm{ha}^{-1}$ at 0,2 , and 4 weeks after planting had no significant effect on all vegetative and generative variables observed in sweet corn.

Vegetative growth of maize is associated with increasing the size and number of cells in a plant. Growth of maize plants includes a germination phase followed by a vegetative growth phase which includes enlargement of the stalks, leaves, and roots of the plant which eventually slows down when entering the generative phase. Indicators of vegetative plant growth can be seen from fresh stover weight of plants because it is an accumulation of all vegetative organs of the plant. Sitompul \& Guritno (1995) states that plant biomass includes all plant material which is roughly derived from the results of photosynthesis, nutrient uptake, and water treated through biosynthetic processes. The results of the analysis of variance showed that the dolomite application significantly affected the fresh stover weight of sweet corn plants. The fresh stover weight of a plant is the weight of the plant when it is still alive and is weighed immediately after harvesting before the plant will wilt due to water loss (Lakitan, 1996).

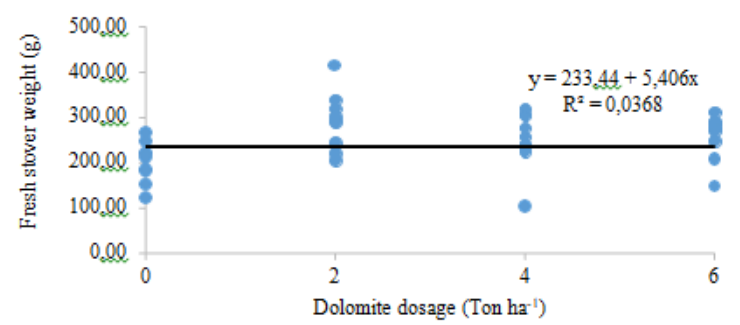

Figure 2. Relationship between dolomite dosage and fresh stover weight of sweet com plants 
The pattern of dolomite dosage relation to the fresh weight of sweet corn plants formed a positive linear pattern with the equation $y=233.44+5.406 x$ and the coefficient of determination $\mathrm{R}^{2}=0.037$ (Figure 2). This means that each additional one unit dose of dolomite will be accompanied by an increase in fresh weight of sweet corn plants by an average of $5.41 \mathrm{~g}$. Fresh plant weight is influenced by vegetative organs of plants such as plant height. This can be seen from the results of correlation analysis which shows the fresh weight of plants is positively correlated with plant height with a value of 0.81 . Plant height is one of the factors that determine the vegetative growth rate of plants. The administration of various doses of dolomite to the variable height of sweet corn plants formed a positive linear relationship curve with the equation $\mathrm{y}=161.99+2.479 \mathrm{x}$ and the coefficient of determination $\mathrm{R}^{2}=0.096$ (Figure 3). This means that each addition of one dolomite dose unit will be accompanied by an increase in sweet corn plant height an average of $2.48 \mathrm{~cm}$.

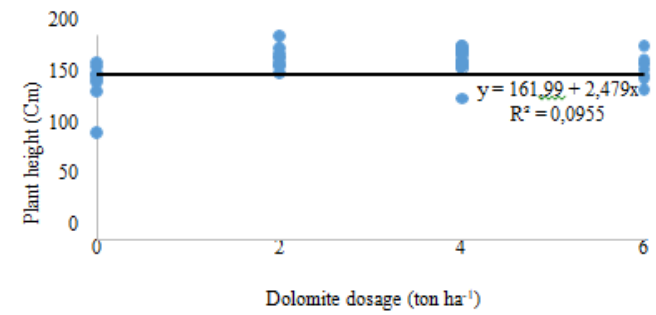

Figure 3. Relationship between dolomite dosage and sweet com plant height

Vegetative organs of plants that also affect the fresh weight of plants are the total leaf area. This can be seen from the results of the correlation analysis which shows the fresh weight of plants is positively correlated with the total area of plant leaves with a value of 0.7599 . The total leaf area of the plant showed a significant effect on the dose of dolomite given. The pattern of dolomite dose relationship to the total leaf area of sweet corn plants formed a positive linear pattern with the equation $\mathrm{y}=4627.4+$ $127.95 \mathrm{x}$ and the coefficient of determination $\mathrm{R}^{2}=$ 0.0696 (Figure 4). This means that each addition of one dolomite dose unit will be accompanied by an increase in total leaf area on average by $127.95 \mathrm{~cm}^{2}$.

The increase in total leaf area which is getting wider is thought to be caused by optimal plant growth space with a spacing of $40 \mathrm{~cm} \times 60 \mathrm{~cm}$ so that among sweet corn plants have a low level of competition against nutrient absorption, water and sunlight intensity associated with leaf area formation of the sweet corn plant. Increasing the total leaf area allows plants to utilize light more optimally in photosynthesis to produce higher photosynthates that support the growth of leaves and other organs (Salisbury \& Ross, 1992).
Vegetative organ accumulation in fresh plant weight affects the weight of plant dry weight. This

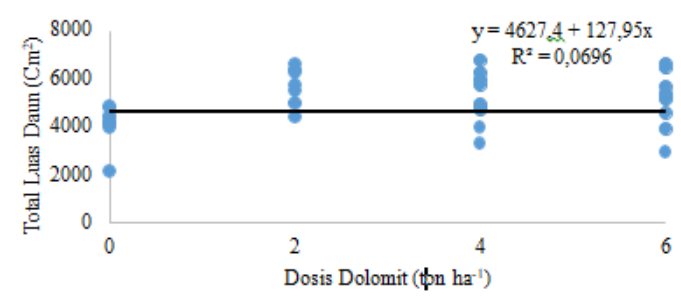

Figure 4.Relationship between dolomite dosage and total leaf area of sweet com

can be seen from the results of the analysis which shows the fresh weight of plants is positively correlated with a dry weight of plants with a value of 0.596. Dry weights plant produces the amount of biomass that can be absorbed by plants during vegetative growth. According to Larcher (1975), plant dry weight is the result of photosynthate accumulation, and $\mathrm{CO}_{2}$ assimilation carried out during plant growth and development. Plant dry weight is an indicator that illustrates the result of the process of photosynthesis is photosynthate in plants that do not contain air. The pattern of dolomite dosage relationship to the dry weight of sweet corn plants formed a positive linear pattern with the equation $\mathrm{y}=115.76$ $+5.384 \mathrm{x}$ and the coefficient of determination $\mathrm{R}^{2}=$ 0.079 (Figure 5). This means that each increase in dolomite dosage will be accompanied by an increase in the weight of sweet corn plants an average of $5.384 \mathrm{~g}$.

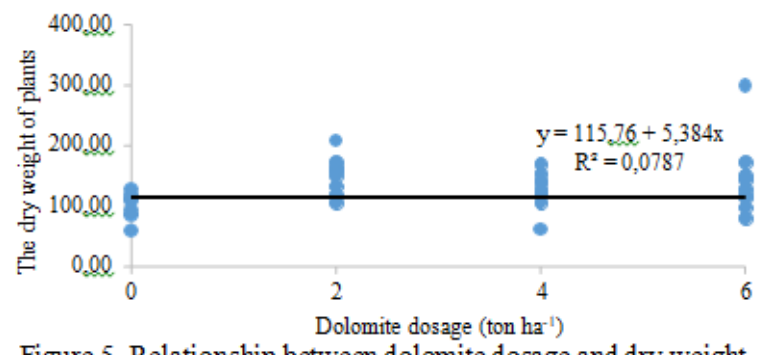

Figure 5. Relationship between dolomite dosage and dry weight of sweet com plants

Dolomite also gives an influence on the generative phase of sweet corn, in this case affecting all yield components observed in this study, which consists of weights of corn without any cornhusk, ear length without husk, and ear diameter without husk. The relationship between dolomite dosage to the weight of corn without any cornhusk formed a positive linear pattern with the equation $\mathrm{y}=151.96+$ $8.33843 \mathrm{x}$ and the coefficient of determination $\mathrm{R}^{2}=$ 0.189 (Figure 6). This means that each addition of one unit dose of dolomite will be accompanied by 
an increase in the weight of corn without any cornhusk an average of $8.384 \mathrm{~g}$.

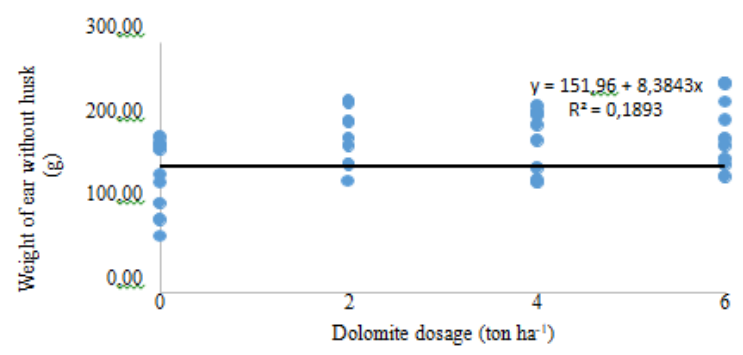

Figure 6. Relationship between dolomite dosage and weight of ear without husk of sweet com

The weight of corn without any cornhusk is influenced by the length of corn without any cornhusk. This can be seen from the results of the correlation analysis which shows the weight of corn without any cornhusk is positively correlated with the length of corn without any cornhusk with a value of 0.895 . The pattern of dolomite dose relation to the length of the corn without any cornhusk forms a positive linear pattern with the equation $\mathrm{y}=19,721+0.325 \mathrm{x}$ and the coefficient of determination $\mathrm{R}^{2}=0.216$ (Figure 7). This means that each addition of one unit dose of dolomite will be accompanied by an increase in the length of the corn without any cornhusk by an average of $0.325 \mathrm{~cm}$.

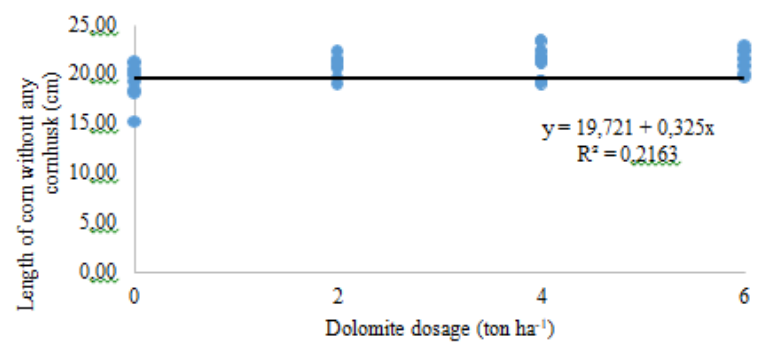

Figure 7. Relationship between dolomite dosage and ear length without husk of sweet com

Increasing the length of the corn without any cornhusk is directly proportional to the increasing diameter of the corn without any cornhusk. This can be seen from the results of the correlation analysis showing the length of the corn without cornhusk is positively correlated with the diameter of the corn without any cornhusk with a value of 0.912 . The pattern of dolomite dose relationship with the diameter of the corn without any cornhusk formed a positive linear pattern with the equation $\mathrm{y}=3.8604+0.067 \mathrm{x}$ and the coefficient of determination $\mathrm{R}^{2}=0.196$ (Figure 8). This means that each addition of one unit dose of dolomite will be accompanied by an increase in the diameter of the corn without any cornhusk by an average of $0.067 \mathrm{~cm}$.
The length and diameter of the corn without any cornhusk influences the yield of sweet corn. The greater the length and the diameter of the corn without any cornhusk they have, the greater the weight of sweet corn in this study. The average weight of corn without any cornhusk produced in this study reached $6.376 \mathrm{~kg} \mathrm{plot}^{-1}$ which is equivalent to 7,116 tons $\mathrm{ha}^{-1}$. This shows that the results obtained are lower when compared with the potential yield in the varieties' description which can reach 8.6125 tons $\mathrm{ha}^{-1}$. The potential yield of sweet corn has not yet been achieved, presumably because nutrients are still insufficient for sweet corn. The provision of dolomite is expected to increase $\mathrm{pH}$ and also add $\mathrm{Ca}$ and $\mathrm{Mg}$ content to increase plant growth and development. But the results of research Susilawati et al. (2015) show that the use of dolomite has no significant effect on all components of soybean growth which is suspected because dolomite has not been decomposed and is absorbed directly by soil and plants.

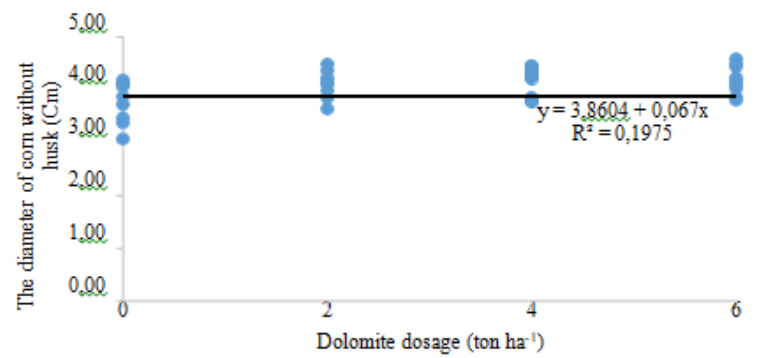

Figure 8. Relationship between dolomite dosage and diameter of com without any cornhusk of sweet com

Dolomite is also able to reduce the exchangeable $\mathrm{Al}$, increase the content of $\mathrm{Ca}$ and $\mathrm{Mg}$, and improve the availability of $\mathrm{P}$ in Ultisols. This has an impact on increasing sweet corn yield. If the soil is acidic, many $\mathrm{Al}$ elements are found that can toxic plants and bind $\mathrm{P}$. So that $\mathrm{P}$ cannot be absorbed by plants (Mutert \& Adiningsih, 1996). Saputro et al. (2017) showed that the application of dolomite 0 tons $\mathrm{ha}^{-1}, 1$ ton ha ${ }^{-1}$, and 2 tons ha $^{-1}$ to soybean plants did not significantly affect all observed parameters. This is due to the soil $\mathrm{pH}$ being too low, causing aluminum and ferrous are toxic to the plants. Besides, the growth of nodule bacteria and the process of nitrification are inhibited. These conditions have an impact on the availability of $\mathrm{N}$ that play a role in plant growth. Munir (1996) states that $\mathrm{N}$ becomes unavailable to plants because it is bound by $\mathrm{Al}^{3+}, \mathrm{Mg}^{2+}$, and $\mathrm{Fe}^{3+}$ ions to acid soils. Nitrogen is an important element in the formation of chlorophyll, protoplasm, protein, and nucleic acids. Element $\mathrm{N}$ greatly influences the formation of the ear on corn plants. Nitrogen is a major component in the process of protein synthesis (Brady $\&$ Weil, 2002). If the synthesis goes well, it will pos- 
itively correlate to the increase in the size of the ears, both in terms of the length and diameter of the ears, so that the potential yield of sweet corn can be fulfilled.

\section{CONCLUSION}

Based on the results of this study, it can be concluded that: interaction between the application of 10 tons ha ${ }^{-1}$ palm oil sludge and 3.61 tons ha ${ }^{-1}$ dolomite produces a maximum stalk diameter of sweet corn plants of $1.98 \mathrm{~cm}$; the application of palm oil sludge had no significant effect on all observed growth and yield variables of sweet corn; giving dolomite dosage up to 6 tons ha $^{-1}$ can increase plant height, total leaf area, the weight of corn without any cornhusk, ear length without husk, ear diameter without husk, ear weight, and dry weight of sweet corn

\section{References}

Ahmad, Y. (2010). Analysis kadar hara makro dalam tanah pada tanaman agroforestri di Desa Tambun Raya Kalimantan Tengah. Jurnal Hutan Tropis. 11(30), 37-46.

Bradford, K.L. \& Yang, S.P. (1981). Physiological response of plants to water logging. Hort Sci., 16(1), 25-28.

Brady, N. C. \& Weil, R.R. (2002). The Nature and Properties of Soils. 13th Edition. Upper Saddle River, New Jersey, USA.

Ermadani. (2010). Perbaikan sifat kimia tanah Ultisols dan pertumbuhan Calopogonium dengan pengapuran dan pemupukan N, P dan K. Jurnal Penelitian Universitas Jambi Seri Sains. 12(2), 07-12.

Fachdarisman, F. 2013. Takaran bahan organik blotong tebu terhadap pertumbuhan dan hasil tanaman jagung manis (Zea mays saccharata Sturt). Skripsi. Program Studi Agroteknologi. Fakultas Pertanian. Universitas Taman Siswa. Padang.

Gomez, A. A. \& Gomez, K.A. (1984). Statistical Procedures for Agricultural Research. 2nd Ed. John Wiley and Sains, Inc., London.

Gustianty, L. R. \& Hasibuan, S. (2017). Pengaruh pupuk solid dan sekam padi terhadap pertumbuhan dan produksi tanaman pakcoy (Brassica rapa L). Bernas. 13(1), 22-30.

Hakim, L. \& Sediyarsa, M. (1986). Percobaan perbandingan beberapa sumber pupuk fosfat alam di daerah Lampung Utara. hal. 179-194. In U. Kurnia, J. Dai, N. Suharta, I. P. G. WidjayaAdhi, J. Sri Adiningsih, S. Sukmana, J. Prawira Sumantri (Ed.). Prosiding Pertemuan Teknis Penelitian Tanah, Cipayung, 10-13 November 1981. Pusat Penelitian Tanah, Bogor.
Hidayat, A. \& Mulyani. (2003). Lahan kering untuk pertanian dalam buku teknologi pengelolaan lahan kering. Hal $1-34$. Pusat Penelitian dan Pengembanga Tanah dan Agroklimat, Bogor.

Ispandi, A. \& Munip, A. (2005). Efektifitas pengapuran terhadap serapan hara dan produksi beberapa klon ubikayu di lahan kering masam. Jurnal Ilmu Pertanian, 12(2), 125-139.

Jenny, M. U. \& Suwadji, E. (1999). Pemanfaatan Limbah Minyak Sawit (Sludge) sebagai Pupuk Tanaman dan Media Jamur Kayu. BATAN, Bogor.

Jumakir, Waluyo. \& Suparwoto. (2000). Kajian berbagai kombinasi pengapuran dan pemupukan terhadap pertumbuhan dan produksi kacang tanah (Arachis hypogea L.) di lahan pasang surut. Jurnal Agronomi 8(1), 11-15.

Lakitan, B. (1996). Dasar-Dasar Fisiologi Tumbuhan. PT. Radja Grafindo Persada, Jakarta.

Larcher, W. (1975). Physiological Plant Ecology: Ecophysiology and Stress Physiology of Functional Groups. Third Edition. Springer, New York.

Leiwakabessy, F. M. (1998). Kesuburan Tanah. Pertanian, Institut Pertanian Bogor, Bogor.

Marvelia, A. \& Sri, D. (2006). Produksi tanaman Jagung manis (Zea mays Saccharata Sturt.) yang diperlakukan dengan kompos kascing dengan dosis yang berbeda. Buletin Anatomi dan Fisiologi. 14(2), 7-18.

McFarlane \& Williamson, D.R. (2001). Water and rivers commission, 3 plain street, East Perth, WA 6004. Australia. Agriculture Water Management.http://www.sciencedirect.com/science/ journal/03783774.

Muamar, Z. A., Triyono, T. \& Rosadi, B. (2012). Analisis neraca air tanaman jagung (Zea mays) di Bandar Lampung. Jurnal Teknik Pertanian Lampung. 1(1), 1 -10 .

Munir, M. (1996). Tanah-Tanah Utama Indonesia. Dunia Pustaka Jaya, Jakarta.

Mutert, E. W. \& JAdiningsih, J.S. (1996). Tropical upland improvement: comparative performance of different phosphorus source. p. 97-108. In Nutrient Management for Sustainable Crop Production in Asia. Proc. Of an International Conference held in Bali, Indonesia, 9-12 December 1996.

Nugroho, J. S., Gusmara, H. \& Simanihuruk, B.W. (2017). Pengaruh lumpur sawit dan NPK sintetik terhadap pertumbuhan dan hasil tanaman jagung. Agritrop: Jurnal Ilmu-Ilmu Pertanian (Journal of Agricultural Science). 14(2), 114-119.

Nyakpa, M. Y., Lubis, A.M., Pulung, M.A., A.G. Amrah, Munawar, A., Hong, G.B. \& Hakim, N. (1988). 
Kesuburan Tanah. Penerbit Universitas Lampung. Lampung.

Pandapotan, C.D. (2016). Pemanfaatan limbah lumpur padat (sludge) pabrik pengolahan kelapa sawit sebagai alternatif penyediaan unsur hara di tanah Ultisols. Jurnal Agroekoteknologi Universias Sumatera Utara. 5 (2) : 271-276.

Purwono, M. \& R. Hartono. (2007). Bertanam Jagung Manis. Penebar Swadaya, Bogor.

Salisbury, F. B. \& Ross, C.W. (1992). Plant Physiology. 4th Ed. Wadsworth Publishing Company Bellmount, California.

Saputro, W., Sarwitri, R. \& Ingesti,P.S.V. (2017). Pengaruh dosis pupuk organik dan dolomit pada lahan pasir terhadap pertumbuhan dan hasil tanaman kedelai (Glycine max, L. Merrill). Jurnal Ilmu Pertanian Tropika dan Subtropika (Journal of Tropical and Subtropical Agricultural Sciences). 2(2), 70-73.

Sari, D. P., Gusmara, H. \& Simanihuruk, B.W. (2017). Pertumbuhan dan hasil jagung manis (Zea mays saccharata) dengan pengurangan pupuk NPK yang digantikan dengan lumpur kelapa sawit (sludge) pada tanah Ultisols. Agritrop: Jurnal Ilmu-Ilmu Pertanian (Journal of Agricultural Science). 15(1), 138-150.

Siagian, D.M., Simanihuruk, B.W. \& Gusmara, H. (2019). Waktu pemberian lumpur sawit dan dosis NPK pada pertumbuhan dan hasil jagung manis (zea mays saccharata sturt.) di Ultisols. Jurnal Ilmu-Ilmu Pertanian Indonesia (Indonesian Journal of Agricultural Science). 21(1), 27-31.

Sitompul, S. M. \& Guritno, B. (1995). Analisis Pertumbuhan Tanaman. Gadjah Mada University Press, Yogyakarta.
Soepardi, G. (2000). Sifat dan Ciri Tanah. Jurusan Tanah. Fakultas Pertanian, Institut Pertanian Bogor, Bogor

Sri Adiningsih, J., Setyorini, D. \& Prihatini, T. (1995). Pengelolaan Hara Terpadu untuk Mencapai Produksi Pangan yang Mantap dan Akrab Lingkungan. Prosiding Pertemuan Teknis Penelitian Tanah dan Agroklimat. Makalah Kebijakan. Bogor 10-12 Januari 1995. Puslittanak, Bogor.

Susilawati, S., Subatra, K., Suwigno, R.A. \& Hayati, R. (2015). Adaptasi beberapa varietas unggul kedelai yang berdaya hasil tinggi dengan pemberian dolomit dan urea di lahan pasang surut. Jurnal Lahan Suboptimal. 3(2), 126-131.

Susilo, D.E.H. (2015). Identifikasi nilai konstanta bentuk daun untuk pengukuran luas daun metode panjang kali lebar pada tanaman hortikultura di tanah gambut. Anterior Jurnal. 14 (2), 139146.

Sutedjo, M. M. (2010). Pupuk dan Cara Pemupukan. PT. Rieneka Cipta, Jakarta.

Sutriadi, M.T., Hidayat, R., Rochayati, S. \& Setyorini, D. (2005). Amelorasi Lahan Dengan Fosfat Alam Untuk Perbaikan Kesuburan Tanah Kering Masam Typic Hapludox Di Kalimantan Selatan. hal 143-155 Dalam Prosiding Seminar Nasional Inovasi Teknologi Sumber Daya Tanah dan Iklim. Buku II. Bogor, 14-15 September 2004. Pusat Penelitian dan Pengembangan Tanah dan Agroklimat, Bogor.

Syukur, M. \& Aziz, R. (2013). Jagung Manis. Penebar Swadaya, Jakarta.

Thompson, L. M. \& Troeh, F.R. (1978). Soil and Fertility. Mc Graw-Hill Book Company, London.

Wahyono, S., Sahwan, F.L., Martono, J.H. \& Suyanto, F. (2008). Evaluasi Teknologi Penanganan Limbah Padat Industri Sawit. Prosiding Seminar Teknologi untuk Negeri, BPPT. 